\title{
Pengaruh Umur Induk dan Lama Penyimpanan terhadap Kualitas Internal Telur Ayam Kedu Jengger Hitam
}

\section{The Effect of Hen Age and Storage Time Duration on The Egg Internal Quality of Black Comb Kedu Chicken}

\author{
M. Baharudin, E. Kurnianto*, dan S. Kismiati \\ Fakultas Peternakan dan Pertanian Universitas Diponegoro, Semarang \\ *E-mail: kurniantoedy17@gmail.com \\ (Diterima: 30 Mei 2019; Disetujui: 20 Juli 2019)
}

\begin{abstract}
ABSTRAK
Penelitian ini bertujuan untuk mengetahui pengaruh umur induk dan lama penyimpanan terhadap kualitas internal telur ayam kedu jengger hitam. Penelitian dilaksanakan mulai bulan September sampai dengan November 2018 di Balai Pusat Bibit Ternak Non Ruminansia (BPBTNR) Satker Ayam Maron, Kabupaten Temanggung, Jawa Tengah. Materi penelitian ini adalah 60 butir telur yang berasal dari 18 ekor ayam kedu jengger hitam berumur 61-65 minggu. Rancangan acak lengkap pola faktorial 5 x 4 dengan 3 kali ulangan diterapkan pada penelitian ini. Faktor pertama adalah umur induk yaitu 61, 62, 63, 64, dan 65 minggu. Faktor kedua yaitu lama penyimpanan 1, 3, 5 dan 7 hari. Parameter yang diamati meliputi indeks kuning telur, haugh unit, dan indeks putih telur. Data dianalisis dengan prosedur General Linear Model (GLM) program Statistical Analysis System (SAS) Versi 6.12. Jika perlakuan berpengaruh nyata terhadap parameter yang diamati, maka dilanjutkan dengan uji Duncan multiple range test. Hasil penelitian memperlihatkan bahwa tidak terdapat pengaruh interaksi antara umur induk dan lama penyimpanan terhadap kualitas internal telur. Umur induk tidak berpengaruh nyata terhadap kualitas internal telur, sementara itu, lama penyimpanan berpengaruh nyata $(\mathrm{P}<0,05)$ terhadap kualitas internal telur. Simpulan penelitian ini, kualitas internal telur tidak mengalami penurunan pada umur induk 61-65 minggu. Namun, kualitas internal telur menurun seiring dengan makin lama waktu penyimpanan telur.
\end{abstract}

Kata kunci: ayam Kedu, kualitas internal telur, lama penyimpanan, umur induk

\section{ABSTRACT}

The objectives of study to determine the effect of hen age and storage time duration on the egg internal quality of black comb kedu chicken. The study was conducted from September to November 2018 at Balai Pusat Bibit Ternak Non-Ruminansia (BPBTNR) Satker Ayam Maron, Temanggung District, Central Java. Sixty eggs from 18 black combs Kedu chicken aged 61-65 weeks were used as materials. Completely Randomized Design (CRD) $5 \times 4$ with three replications was applied. The first factor was the age of hen, which was 61, 62, 63, 64, and 65 weeks. The second factor was storage duration of 1, 3, 5, and 7 days. Parameters were included yolk index, haugh unit, and albumen index. The data were analyzed by General Linear Model (GLM) procedure Statistical Analysis System (SAS) Ver 6.12. If the treatments affected significantly different from the parameters, then it was followed by the Duncan multiple range test. The results showed that there was no interaction between hen age and storage duration on egg internal quality. Hen age had no significant effect on egg internal quality, whereas the storage time duration had significant effect $(P<0.05)$ on on egg internal quality. In conclusion, egg internal quality did not decrease at the layer age of 61-65 weeks. However,egg internal quality decreased with increasing egg storage duration.

Keywords: egg internal quality, hen age, Kedu chicken, storage duration 


\section{PENDAHULUAN}

Ayam Kedu merupakan ayam lokal Indonesia yang banyak dipelihara di daerah Kabupaten Temanggung, Jawa Tengah dan merupakan ayam hasil persilangan dari ayam dorking dengan ayam buras yang ada di daerah Dieng (Sujionohadi dan Setiawan, 2013). Ayam Kedu dibedakan menjadi tiga berdasarkan warna bulunya yaitu Kedu hitam, putih, dan lurik. Ayam Kedu hitam memiliki warna bulu hitam mengkilap dengan paruh dan cakar berwarna gelap kehitaman. Ayam Kedu merupakan tipe dwiguna yang dapat dipelihara untuk dimanfaatkan dagingnya maupun telurnya. Ayam Kedu memiliki beberapa keunggulan antara lain tahan terhadap penyakit, jinak, mudah dipelihara dan dapat menghasilkan telur yang baik serta memiliki daging yang padat (Johari et al., 2009). Produktivitas telur ayam Kedu lebih tinggi dibanding dengan ayam lokal lainnya. Produktivitas telur yang tinggi harus diiringi dengan penanganan telur yang baik dan benar agar kualitas telur yang dihasilkan baik.

Ayam Kedu yang berada di masyarakat belum sepenuhnya murni. Kegiatan pemurnian perlu dilakukan untuk menghasilkan galur murni sehingga ayam Kedu terhindar dari kepunahan. Salah satu upaya pemurnian yaitu dengan perbanyakan populasi ayam kedu melalui proses penetasan. Proses penetasan telur dipengaruhi oleh kualitas telur tetas. Telur dengan kualitas baik akan menghasilkan produk penetasan yang baik pula. Kualitas telur dibedakan menjadi dua, yaitu eksternal dan internal. Kualitas eksternal diketahui berdasarkan bobot, bentuk telur, dan kondisi kerabang telur. Kualitas secara internal diketahui berdasarkan warna kuning telur, haugh unit, indeks kuning telur, dan indeks putih telur (Kunaifi et al., 2019).

Kualitas internal telur dipengaruhi oleh umur induk dan lama penyimpanan. Kualitas internal telur akan menurun seiring bertambahnya umur induk. Umur yang semakin tua akan menghasilkan kerabang tipis sehingga mempercepat penurunan kualitas internal telur. Kualitas internal telur menurun seiring bertambahnya lama penyimpanan. Penurunan kualitas internal telur selama penyimpanan disebabkan oleh beberapa faktor antara lain penguapan komponen telur dan perpindahan air dari putih telur menuju kuning telur. Penurunan kualitas internal telur selama penyimpanan akan mempengaruhi perkembangan embrio. Semakin lama telur disimpan, kandungan nutrisi telur akan mengalami penurunan sehingga mempengaruhi perkembangan embrio dan berdampak pada hasil penetasan.

Tujuan dari penelitian ini adalah untuk mengetahui pengaruh umur induk dan lama penyimpanan terhadap kualitas internal telur ayam kedu jengger hitam.

\section{METODE}

Penelitian ini dilaksanakan pada bulan September - November 2018 di Balai Pusat Bibit Ternak Non Ruminansia (BPBTNR) Satker Ayam Maron, Kabupaten Temanggung, Jawa Tengah.

Enam puluh butir telur yang berasal dari 18 ekor ayam kedu jengger hitam berumur 61-65 minggu digunakan sebagai materi penelitian. Ayam ditempatkan pada 3 pen, masing-masing pen terdiri dari 1 jantan dan 5 betina. Alat yang digunakan adalah kaca, jangka sorong, depth micrometer, sendok, timbangan, dan alat tulis. Kaca digunakan sebagai tempat memecah telur. Jangka sorong digunakan untuk mengukur panjang dan lebar putih telur, serta untuk mengukur diameter kuning telur. Depth micrometer digunakan untuk mengukur ketinggian kuning telur dan putih telur. Sendok digunakan untuk memisahkan kuning telur dan putih telur. Timbangan digunakan untuk menimbang telur, putih telur, dan kuning telur serta alat tulis digunakan untuk mencatat data dan hasil penelitian.

Rancangan acak lengkap pola faktorial 5 x 4 dengan 3 kali ulangan digunakan pada penelitian ini. Faktor pertama adalah umur 
Tabel 1. Rataan indeks kuning telur ayam Kedu jengger hitam

\begin{tabular}{ccccccc}
\hline \multirow{2}{*}{$\begin{array}{c}\text { Lama } \\
\text { Simpan } \\
\text { (hari) }\end{array}$} & 61 & 62 & 63 & 64 & 65 & Rataan \\
\cline { 2 - 5 } & 0,424 & 0,415 & 0,400 & 0,424 & 0,407 & $0,414^{\mathrm{a}}$ \\
\hline 1 & 0,368 & 0,407 & 0,379 & 0,374 & 0,381 & $0,382^{\mathrm{b}}$ \\
3 & 0,332 & 0,345 & 0,326 & 0,359 & 0,342 & $0,337^{\mathrm{c}}$ \\
5 & 0,299 & 0,325 & 0,323 & 0,354 & 0,316 & $0,321^{\mathrm{c}}$ \\
\hline 7 & 0,356 & 0,377 & 0,357 & 0,385 & 0,361 & \\
\hline Rataan & &
\end{tabular}

Keterangan: Superskrip yang berbeda pada kolom rataan yang sama menunjukkan perbedaan yang nyata $(\mathrm{P}<0,05)$

induk yaitu 61 minggu, 62 minggu, 63 minggu, 64 minggu, dan 65 minggu. Faktor kedua yaitu lama penyimpanan 1 hari, 3 hari, 5 hari dan 7 hari.

Koleksi telur dilakukan setiap hari sebelum pemberian pakan dan minum. Telur yang dikoleksi diberi tanda untuk memudahkan dalam pengambilan data. Telur yang telah diberi kode kemudian dimasukkan kedalam ruang penyimpanan pada suhu ruang dengan rata-rata pagi $21,22^{\circ} \mathrm{C}$, siang $23,47^{\circ} \mathrm{C}$, sore $23,94^{\circ} \mathrm{C}$ dan kelembapan pagi $65,55 \%$, siang $60,45 \%$ dan sore $58,33 \%$. Parameter yang diamati meliputi indeks kuning telur (IKT), haugh unit (HU), dan indeks putih telur (IPT).

Data yang diperoleh dianalisis dengan prosedur General Linear Model (GLM) program Statistical Analysis System (SAS) Versi 6.12. Jika perlakuan berpengaruh nyata terhadap paramater, maka dilanjutkan dengan uji Duncan multiple range test.

\section{HASIL DAN PEMBAHASAN}

\section{Indeks Kuning Telur (IKT) Ayam Kedu Jengger Hitam}

Rataan IKT tiap kombinasi perlakuan umur induk dan lama penyimpanan dapat dilihat pada Tabel 1. Rataan IKT selama penelitian sebesar 0,299-0,424.

Tidak terdapat pengaruh interaksi antara umur induk dengan lama simpan terhadap IKT (Tabel 1). Umur induk tidak berpengaruh nyata terhadap IKT, sedangkan lama penyimpanan berpengaruh nyata $(\mathrm{P}<0,05)$ terhadap IKT.

Umur induk pada penelitian ini tidak berpengaruh nyata terhadap IKT karena perbedaan umur induk yang digunakan hanya 1 minggu. Hasil penelitian Padhi et al. (2013) menunjukkan bahwa perbedaan umur induk 12 minggu berpengaruh nyata terhadap IKT.

IKT mengalami penurunan secara nyata selama proses penyimpanan, akan tetapi pada umur penyimpanan 5 dan 7 hari tidak berbeda nyata. Hal ini dikarenakan semakin bertambahnya umur penyimpanan, kondisi kuning telur menjadi semakin encer. Menurut Thohari (2018) kondisi kekentalan kuning telur berubah selama proses penyimpanan. Indeks kuning telur dipengaruhi oleh tinggi kuning telur dan diameter kuning telur. Tinggi kuning telur akan menurun selama proses penyimpanan dan menyebabkan IKT menurun. Hasil penelitian Raji et al. (2009) menunjukkan bahwa IKT menurun seiring dengan menurunnya tinggi kuning telur. Menurunnya tinggi kuning telur diakibatkan karena berpindahnya air dari putih telur menuju kuning telur (Stadelman dan Cotterill, 1977). Soeparno et al. (2011) menyatakan bahwa pada suhu $10 \mathrm{oC}$ air yang berpindah dari putih telur menuju kuning telur sebanyak $10 \mathrm{mg} / \mathrm{hari}$.

IKT pada penelitian ini menurun pada lama penyimpanan 3 hari. Hal ini berbeda 
Tabel 2. Rataan haugh unit telur ayam Kedu jengger hitam

\begin{tabular}{ccccccc}
\hline \multirow{2}{*}{$\begin{array}{c}\text { Lama } \\
\text { Simpan } \\
\text { (hari) }\end{array}$} & 61 & 62 & 63 & 64 & 65 & Rataan \\
\cline { 2 - 5 } & 69,197 & 70,620 & 66,353 & 56,643 & 69,053 & $66,070^{\text {a }}$ \\
\hline 1 & 61,590 & 50,267 & 57,493 & 50,133 & 53,790 & $54,716^{\text {b }}$ \\
3 & 58,253 & 52,840 & 42,400 & 48,610 & 53,585 & $51,220^{\text {bc }}$ \\
5 & 56,757 & 52,440 & 34,057 & 44,885 & 38,670 & $44,854^{\text {c }}$ \\
7 & 61,449 & 55,844 & 50,076 & 50,968 & 53,792 & \\
\hline Rataan & &
\end{tabular}

Keterangan: Superskrip yang berbeda pada kolom rataan yang sama menunjukkan perbedaan yang nyata $(\mathrm{P}<0,05)$

dengan hasil penelitian Khan et al. (2013), bahwa IKT menurun pada lama penyimpanan 6 hari dengan suhu $16^{\circ} \mathrm{C}$. Perbedaan hasil ini dikarenakan suhu penyimpanan pada penelitian ini berkisar antara $21-24^{\circ} \mathrm{C}$. Hasil penelitian Samli et al. (2005) menunjukkan bahwa perbedaan suhu penyimpanan berpengaruh nyata terhadap IKT. Menurut Akter et al. (2014) suhu penyimpanan yang tinggi akan mempercepat proses penguapan komponen telur.

IKT dalam penelitian ini hanya perlakuan lama penyimpanan 7 hari yang tidak memenuhi standar SNI. Menurut Badan Standarisasi Nasional (2008), IKT yang baik berkisar antara 0,330-0,521.

\section{Haugh Unit (HU) Telur Ayam Kedu Jengger Hitam}

Rataan HU telur tiap kombinasi perlakuan umur induk dan lama penyimpanan disajikan pada pada Tabel 2. Rataan HU telur selama penelitian sebesar 34,057-70,620.

Tidak terdapat pengaruh interaksi antara umur induk dengan lama simpan terhadap nilai HU telur (Tabel 2). Umur induk tidak berpengaruh nyata terhadap HU telur, sedangkan lama penyimpanan berpengaruh nyata $(\mathrm{P}<0,05)$ terhadap HU telur.

Umur induk pada penelitian ini tidak berpengaruh nyata terhadap HU telur karena perbedaan umur induk yang digunakan hanya 1 minggu. Hasil penelitian Rajkumar et al. (2009) menunjukkan bahwa perbedaan umur induk 4 minggu berpengaruh nyata terhadap HU telur.

HU telur dari lama penyimpanan 1 hari hingga 7 hari mengalami penurunan. Penurunan ini disebabkan karena tinggi putih telur mengalami penurunan selama penyimpanan. Hal ini sesuai dengan penelitian yang dilakukan Samli et al. (2005) bahwa selama proses penyimpanan tinggi putih telur mengalami penurunan dan mengakibatkan $\mathrm{HU}$ telur menurun. Penurunan tinggi putih telur disebabkan oleh proses penguapan. Proses penguapan yang terjadi dipengaruhi oleh suhu selama penyimpanan. Semakin tinggi suhu penyimpanan maka penguapan akan berjalan semakin cepat. HU telur penelitian ini menurun pada penyimpanan 3 hari. Hal ini berbeda dengan Khan et al. (2013), bahwa haugh unit menurun pada lama penyimpanan 6 hari dengan suhu $16^{\circ} \mathrm{C}$. Perbedaan hasil ini dikarenakan suhu penyimpanan yang digunakan dalam penelitian berbeda. Suhu penyimpanan pada penelitian ini berkisar antara $21-24^{\circ} \mathrm{C}$. Penelitian Chung dan Lee (2014) menunjukkan bahwa HU telur dipengaruhi oleh suhu penyimpanan.

Hasil penelitian ini hanya telur dengan perlakuan lama penyimpanan 1 hari yang memiliki kualitas A, sedangkan telur dengan lama penyimpanan 3, 5, 7 hari memiliki kualitas B. Menurut United States Department of Agriculture (2000), kualitas telur berdasarkan nilai haugh unit dibedakan menjadi 3 kategori yaitu kualitas AA dengan 
Tabel 3. Rataan indeks putih telur ayam Kedu jengger hitam

\begin{tabular}{|c|c|c|c|c|c|c|}
\hline \multirow{2}{*}{$\begin{array}{c}\text { Lama } \\
\text { Simpan } \\
\text { (hari) }\end{array}$} & \multicolumn{5}{|c|}{ Umur Induk (minggu) } & \multirow{2}{*}{ Rataan } \\
\hline & 61 & 62 & 63 & 64 & 65 & \\
\hline 1 & 0,057 & 0,065 & 0,050 & 0,040 & 0,057 & $0,053^{\mathrm{a}}$ \\
\hline 3 & 0,044 & 0,038 & 0,038 & 0,031 & 0,034 & $0,037^{\mathrm{b}}$ \\
\hline 5 & 0,035 & 0,031 & 0,023 & 0,034 & 0,032 & $0,030^{\mathrm{bc}}$ \\
\hline 7 & 0,032 & 0,035 & 0,020 & 0,027 & 0,021 & $0,026^{\mathrm{c}}$ \\
\hline Rataan & 0,042 & 0,042 & 0,033 & 0,033 & 0,037 & \\
\hline
\end{tabular}

Keterangan: Superskrip yang berbeda pada kolom rataan yang sama menunjukkan perbedaan yang nyata $(\mathrm{P}<0,05)$

HU lebih dari 72, kualitas A dengan HU 6072, dan kualitas B dengan HU kurang dari 60.

\section{Indeks Putih Telur (IPT) Ayam Kedu Jengger Hitam}

Rataan IPT tiap kombinasi perlakuan umur induk dan lama penyimpanan dapat dilihat pada Tabel 3. Rataan IPT selama penelitian sebesar 0,020-0,065.

Tidak terdapat pengaruh interaksi antara umur induk dengan lama simpan terhadap IPT (Tabel 3). Umur induk tidak berpengaruh nyata terhadap IPT, sedangkan lama penyimpanan berpengaruh nyata $(\mathrm{P}<0,05)$ terhadap IPT.

Umur induk pada penelitian ini tidak berpengaruh nyata terhadap IPT karena perbedaan umur induk yang digunakan hanya 1 minggu. Hasil penelitian Padhi et al. (2013) menunjukkan bahwa perbedaan umur induk 12 minggu berpengaruh nyata terhadap IPT.

IPT dari lama penyimpanan 1 hingga 7 hari mengalami penurunan. Hal ini terjadi karena tinggi putih telur mengalami penurunan selama proses penyimpanan. Hasil penelitian Jones dan Musgrove (2005) menunjukkan bahwa tinggi lapisan kental pada putih telur akan menurun seiring bertambahnya lama penyimpanan. IPT dipengaruhi oleh tinggi putih telur kental dan diameter putih telur. Selama proses penyimpanan, tinggi putih telur akan mengalami penurunan sehingga IPT akan menurun. Menurut Tayeb (2012) tinggi putih telur menurun selama proses penyimpanan yang mengakibatkan IPT menurun. Penurunan tinggi lapisan kental pada putih telur disebabkan karena rusaknya lapisan ovomucin pada putih telur sehingga menyebabkan keluarnya air dari dalam putih telur (Stadelman dan Cotterill, 1977).

IPT pada penelitian ini mulai menurun pada lama penyimpanan 3 hari. Hal ini berbeda dengan hasil penelitian dengan Khan et al. (2013), bahwa IPT menurun pada lama penyimpanan 6 hari dengan suhu $16^{\circ} \mathrm{C}$. Perbedaan hasil ini disebabkan karena suhu penyimpanan pada penelitian ini berkisar antara $21^{\circ} \mathrm{C}-24^{\circ} \mathrm{C}$. Menurut Akter et al. (2014) penguapan $\mathrm{CO}_{2}$ dan $\mathrm{H}_{2} \mathrm{O}$ akan semakin cepat pada suhu penyimpanan yang tinggi. IPT pada penelitian ini hanya perlakuan lama penyimpanan 1 hari yang memenuhi standar SNI. Menurut Badan Standarisasi Nasional (2008), IPT yang baik berkisar antara 0,050 0,175 .

\section{KESIMPULAN}

Berdasarkan hasil penelitian disimpulkan bahwa kualitas internal telur ayam kedu jengger hitam tidak mengalami penurunan kualitas pada umur induk 6165 minggu namun mengalami penurunan kualitas seiring dengan bertambahnya lama penyimpanan. Penyimpanan 5 dan 7 hari menghasilkan kualitas internal telur yang rendah. 


\section{DAFTAR PUSTAKA}

Akter, Y., A. Kasim., H. Omar, and A. Q. Sazili. 2014. Effect of storage time and temperature on the quality characteristics of chicken eggs. Journal of Food, Agriculture and Environment. 12(3) :87-92.

Badan Standarisasi Nasional (BSN). 2008. SNI 3926 : 2008 Telur Ayam Konsumsi. BSN. Jakarta.

Chung, S. H. and K. W. Lee. 2014. Effect of hen age, storage duration and temperature on egg quality in laying hens. International Journal of Poultry Science. 13(11): 634-636.

Johari, S., Sutopo. dan A. Santi. 2009. Frekuensi fenotipik sifat-sifat kualitatif ayam Kedu dewasa. Seminar Nasional Kebangkitan Peternakan. Semarang. 20 Mei 2009. Hal 606-616.

Jones, D. R. and M. T. Musgrove. 2005. Effects of extended storage on egg quality factors. Poultry Science. 84(11): 1774-1777.

Khan, M. J. A., S. H. Khan., A. Bukhsh., M. I. Abbass, and M. Javed. 2013. Effect of different storage period on egg weight, internal egg quality and hatchability characteristics of Fayumi eggs. Italian Journal of Animal Science. 12(e51): 323-328.

Kunaifi, M. A., M. Wirapartha, dan I. K. A. Wiyana. 2019. Pengaruh penyimpanan selama 14 hari pada suhu kamar terhadap kualitas eksternal dan internal telur itik di daerah Jimbaran. E-journal Peternakan Tropika. 7(1): 77-88.

Padhi, M. K., R. N. Chatterjee., S. Haunshi, and U. Rajkumar. 2013. Effect of age on egg quality in chicken. Indian Journal of Poultry Science. 48(1): 122-125.

Raji, A. O., J. Aliyu., J. U. Igwebuike, and S. Chiroma. 2009. Effect of storage methods and time on egg quality traits of laying hens in a hot dry climate. ARPN Journal of Agricultural and Biological Science. 4(4): 1-7.

Rajkumar, U., R. P. Sharma., K. S. Rajaravindra, and M. Niranjan. 2009. Effect of genotype and age on egg quality traits in naked neck chicken under tropical climate from india. International Journal of Poultry Science. 8(12): 1151-1155.

Samli, H. E., A. Agma, and N. Senkoylu. 2005. Effects of storage time and temperature on egg quality in old laying hens. J. Appl. Poult. Res. 14: 548-553.

Soeparno., R. A. Rihastuti., Indratiningsih, dan S. Triatmojo. 2011. Dasar Teknologi Hasil Ternak. Gadjah Mada University Press. Yogyakarta.

Stadelman, W. J. and O. J. Cotterill. 1977. Egg Science and Technology. Avi Publishing Company. Connecticut.

Sujionohadi, K. dan A. I. Setiawan. 2013. Ayam Kampung Petelur. Penebar Swadaya. Jakarta.

Tayeb, I. T. 2012. Effects of storage temperature and length on egg quality parameters of laying hen. Journal of Animal Scientist. 1(2): 32-36.

Thohari, I. 2018. Teknologi Pengawetan dan Pengolahan Telur. UB Press. Malang.

United States Departement of Agriculture. 2000. Egg Grading Manual. Agricultural Handbook number 75. Washington DC. 